\title{
Gender dalam Buku Pendidikan Bahasa Arab Al-'Ashri Kelas X: Studi Analisis Teks Pola Diskriminasi Gender
}

\author{
Muhimmatul Choiroh \\ UIN Sunan Ampel Surabaya \\ Email: muhim.hime@gmail.com \\ Mirwan Akhmad Taufiq \\ UIN Sunan Ampel Surabaya \\ Email: mirwan@uinsby.ac.id
}

\begin{abstract}
This article reveals the gender side of the Arabic book "al-Asri class X" which is applied in schools under the auspices of Muhammadiyah East Java. The theme of gender becomes a trending discussion in modern and plural society, this is expected to avoid violence in the social environment of society. This article focuses on studying the patterns and concepts of the presentation of genderbased material, whether gender discrimination is still found in the material or practice questions and even the pictures contained in the book. This research uses descriptive qualitative analysis method with the type of library research, which will explore the research object with a logical description. The findings in this article are the concept of gender in the sample expressed in the form of images and texts with the discovery of the role of injustice between men and women. This can cause gender inequality. Men continue to occupy a central role and women occupy domestic roles. Several forms of discrimination have also been found, including: Stereotypes, Subordination, Marginalization, Double Burden and no Violence patterns found in this book.
\end{abstract}

Keywords: Gender Analysis, Textbooks, Arabic Language Education.

Abstrak

Artikel ini mengungkap sisi gender pada buku bahasa Arab "al-Asri kelas X" yang diterapkan di sekolah-sekolah di bawah naungan Muhammadiyah Jawa Timur. Tema gender menjadi trending pembahasan pada masyarakat modern dan majemuk, hal ini diharapkan agar terhindar dari sikap kekerasan dalam lingkungan sosial masyarakat. Artikel ini fokus pada kajian pola dan konsep penyajian materi berbasis gender, apakah masih ditemukan diskriminasi gender dalam materi atau soal-soal latihan dan bahkan gambar-gambar yang terdapat pada buku tersebut. Penelitian ini menggunakan metode analisis deskriptif kualitatif dengan jenis penelitian kepustakaan, yang akan mengeksplore objek penelitian dengan deskripsi logis. Temuan dalam artikel ini adalah konsep gender dalam sampel dinyatakan dalam bentuk gambar dan teks dengan penemuan ketidakadilan peran antara laki-laki dan perempuan. Hal ini dapat 
menyebabkan ketidaksetaraan gender. Laki-laki tetap menempati peran sentral dan perempuan menempati peran domestik. Beberapa bentuk diskriminasi juga ditemukan, termasuk: Citra Baku (Stereotype), Penomorduaan (Subordination), Peminggiran (Marginalization), Beban Ganda (Double Burden) dan tidak ditemukan pola Kekerasan (Violence) dalam buku ini.

Kata Kunci: Analisis Gender, Buku Bahan Ajar, Pendidikan Bahasa Arab

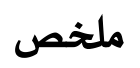

كشفت هذه المقالة عن الجانب الجنسني (gender) للكتاب العربي "al-Asri kelas X" الذي تم تطبيقاه في المدارس تحت رعاية جمعية محمدية بجاوى الشرقية. ويصبح الموضوع الجنسي نقاشًا شـائعًا في المجتمع الحـديث وله تعدد الثقافات، لبغية الوصول إلى اجتناب العنف في المجتمع. وركزت هذه المقالة على دراسة أنماط ومفاهيم عرض المواد القائمة على أشكال الجنس، فهل ذلك التمييز بين الجنسين لا يزال موجودًا في القراءة أو في الأسئلة التدربية أو في الحوار أو في الصيور الواردة في الكتاب. واستخدم

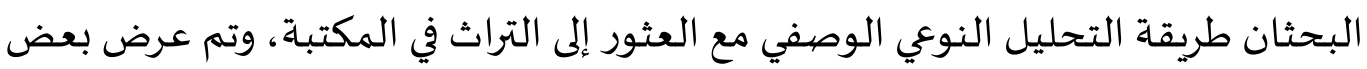
مباحثها بشكل وصهي منطقي. ومن النتائج التي تم اكتشافها في هذه المقالة هي اكتشاف الجانب الجنسي في موضوع الدراسـة بشكل الصيور والنصوص مع اكتشاف عدم التوازن في لعب الدور بين الرجال والنساء. هذا يمكن أن يسبب عدم المساواة بين الجنسين. لعب الرجال في العمل دورا مركزيا وخارجيا واحتلت النساء أدوارًا منزلية فقط. كما تم العثور على العديد من أشكال التمييز، بما في ذلك: القوالب النمطية والتبعية والتهميش والعبء المزدوج ولا توجد أنماط العنف في هذا الكتاب. الكلمة الرئيسية: تحليل النوع الجنسي، الكتب المدرسية، تعليم العنفي هلئ اللفة العربية.

\section{Pendahuluan}

Proses pendidikan formal dan non-formal terkadang tidak selalu berjalan lancar seperti perencanaan yang sudah ditetapkan sebelumnya, terkadang masih menemui rintangan yang harus dihadapi di tengahtengah berjalannya proses pendidikan, terutama bagi para dewan guru dalam merespon perubahan dan perkembangan kurikulum. ${ }^{1}$ Ditemukan beberapa faktor yang dapat memperlambat keberhasilan proses

${ }^{1}$ Apri Damai Sagita Krissandi and Rusmawan Rusmawan, 'KENDALA GURU SEKOLAH DASAR DALAM IMPLEMENTASI KURIKULUM 2013', Jurnal Cakrawala Pendidikan, $2015<$ https://doi.org/10.21831/cp.v3i3.7409>.

El-Ibtikar Vol 9 No 2 Desember 2020 
pendidikan, diantaranya adalah kurangnya ketersediaan buku ajar yang sudah mengikuti perkembangan kurikulum terkini. ${ }^{2}$ Buku ajar menjadi salah satu faktor sentral dalam keberhasilan pendidikan, apalagi ketika dikaitkan dengan pendidikan bahasa Arab di tingkat sekolah. Oleh karena itu, masih ditemukan beberapa sekolah menggunakan buku ajar terbitan timur tengah yang diterapkan langsung di sekolah-sekolah formal, dengan persepsi bahwa buku itu pasti baik, karena dari Arab, walaupun demikian, belum tentu juga buku itu sudah sesuai dengan kurikulum yang ditetapkan oleh pemerintah. ${ }^{3}$ Itu adalah fenomena buku ajar bahasa Arab, tentu akan lebih sulit lagi jika dikaitkan dengan ketersediaan buku bahasa Arab untuk kehidupan dan buku bahasa Arab untuk tujuan khusus (ASP), Arabic for Specific Purpose. ${ }^{4}$ Keberadaan buku-buku itu masih langka di negari ini, terutama yang mengandung unsur-unsur budaya Indonesia dan istilah-istilah baku Indonesia-Arab-nya..

Buku menjadi salah satu sumber acuan guru dalam mengembangkan bahan ajar, sebagai alat bantu pendidik dalam melaksanakan kurikulum dan sebagai bahan referensi atau bahan rujukan oleh peserta didik. Penyajian bahan pembelajaran dalam bentuk buku ini, baik berupa teks atau gambar, dimaksudkan untuk membantu peserta didik memahami isi dalam pokok bahasan pembelajaran. ${ }^{5}$ Hingga isu gender pun tidak luput dari pandangan para pemerhati pendidikan dan masyarakat ketika menelaah buku teks atau buku ajar. Sebab gender sudah menjadi Pandangan yang berkembang sebagai konsep kultural yang mana dipakai untuk membedakan perilaku, mentalitas, peran, dan karateristik emosional antara laki-laki dan perempuan. ${ }^{6}$ Sehingga buku ajar dan buku teks itu mampu mempengaruhi pola pikir peserta didik

2 Niam Wahzudik, 'Kendala Dan Rekomendasi Perbaikan Pengembangan Kurikulum Di Sekolah Menengah Kejuruan', Indonesian Journal of Curriculum and Educational Technology Studies, 2018 <https://doi.org/10.15294/ijcets.v6i2.26712>.

${ }^{3}$ Khairi Abu Syairi, 'Pengembangan Bahan Ajar Bahasa Arab I Abusyairi I Dinamika Ilmu', Dinamika Ilmu, 2013. Hal. 51-66.

${ }^{4}$ Mirwan Akhmad Taufiq, 'منهج تعليم العربية لأغراض خاصة؛ خصائصه ومشكلاته', Arabia, 2018 $<$ https://doi.org/10.21043/ARABIA.V10I2.4275>.

${ }^{5}$ MS ROSYAD, 'ANALISIS BUKU AJAR BAHASA ARAB SISWA KELAS VIII MTs/SMP ISLAM DALAM PERSEPEKTIF GENDER', Journal of Applied Linguistics and Islamic Education, 2.2 (2018) <https://doi.org/http://dx.doi.org/10.33754/jalie.v2i2.188>.

${ }^{6}$ Alfian Rokhmansyah, Pengantar Gender Dan Feminisme:Pemahaman Awal Kritik Sastra Feminisme (Yogyakarta: Garudhawaca, 2016). Hal. 1. 
dengan baik dan memberikan pemahaman gender yang proporsional. Hal ini diharapkan peserta didik terhindar dari stigma negatif gender, bahwa kegiatan, aktivitas dan tugas. perempuan dipandang selayaknya berperan pada sektor domestik saja, sebaliknya pekerjaan publik seperti mencari nafkah diluar rumah, berkarir dan perlindungan keluarga menjadi tugas seorang laki-laki. ${ }^{7}$

Terdapat beberapa penelitian tentang buku ajar dan perspektif gender. Zubaidah Amir membahas gender dalam pembelajaran matematika, ${ }^{8}$ Maman juga mengangkat tema gender dalam buku model sejarah sastra Indonesia, ${ }^{9}$ Endang membahas materi pendidikan seks anak usia dini juga berbasis gender, ${ }^{10}$ Jakfar Shadiq meneliti buku ajar bahasa Arab perspektif gender, ${ }^{11}$ dan masih banyak yang lain beberapa penelitian di bidang ini. Peneliti juga telah melakukan penelitian yang sama dalam perspektif gender, namun dengan objek yang berbeda,yaitu Buku "al-Asri kelas X" yang diajarkan di SMA Muhammadiyah. Peneliti fokus pada kajian pada pola dan konsep penyajian materi berbasis gender, apakah masih ditemukan diskriminasi gender dalam materi atau soal-soal latihan dan bahkan gambar-gambar yang terdapat pada buku pendidikan bahasa Arab Al-`Ashri Kelas X Sekolah Menengah Atas Muhammadiyah.

\section{Metode Penelitian}

Penelitian ini menggunakan pendekatan metode kualitatif, yang diungkap dengan data-data deskriptif tertulis mengulas beberapa polapola gender yang ada pada buku tersebut. Data-data itu dikaji dan dianalisa dengan beberapa fokus kajian gender yang merujuk pada

7 Rokhmansyah ....., Hal. 9.

8 Zubaidah Amir MZ, 'PERSPEKTIF GENDER DALAM PEMBELAJARAN MATEMATIKA', Marwah: Jurnal Perempuan, Agama Dan Jender, 2013 $<$ https://doi.org/10.24014/marwah.v12i1.511>.

9 Maman Suryaman, 'PENGEMBANGAN MODEL BUKU AJAR SEJARAH SASTRA INDONESIA MODERN BERPERSPEKTIF GENDER', LITERA, 2013 $<$ https://doi.org/10.21831/ltr.v12i01.1333>.

10 Tri Endang Jatmikowati, Ria Angin, and Ernawati Ernawati, 'MODEL DAN MATERI PENDIDIKAN SEKS ANAK USIA DINI PERSPEKTIF GENDER UNTUK MENGHINDARKAN SEXUAL ABUSE', Jurnal Cakrawala Pendidikan, 2015 $<$ https://doi.org/10.21831/cp.v3i3.7407>.

${ }^{11}$ Muhammad Jafar Shodiq, 'Perspektif Kesetaraan Gender Dalam Buku Bahasa Arab Siswa MTs Pendekatan Saintifik 2013', Fenomena, 8.1 (2016). Hal. 1-18 $<$ https://doi.org/10.21093/fj.v8i1.302>. 
literatur kepustakaan. Penelitian jenis ini sering disebut dengan Library Research yang memanfaatkan sumber kepustakaan untuk memperoleh data penelitian. ${ }^{12}$ Maka, penelitian ini tidak disajikan dalam bentuk statistik, atau kuantitas jumlah pola gender pada buku al-Asri ini. Penelitian ini hanya mengambil sampel pola-pola gender dan bentuk diskriminasinya jika hal itu ditemukan. Analisis gender akan merujuk kepada beberapa literatur yang punya keterkaitan dengan kajian gender turutama pola gender yang diajukan Julie A. Greenberg yang meliputi, Citra Baku (Stereotype), Penomorduaan (Subordination), Peminggiran (Marginalization), Beban Ganda (Double Burden) dan pola Kekerasan (Violence).

\section{Kerangka Teoritis}

Masyarakat pada umumnya masih memiliki pemahaman bahwa istilah gender itu selalu identik dengan pihak perempuan. Padahal istilah gender dan jenis kelamin (seks) memiliki arti tersendiri yang berbeda. Mayoritas masyarakat masih memiliki pesepsi sama atas dua terma tersebut. Oleh karena itu pengertian atau istilah gender harus difahami dengan benar sesuai dengan peruntukannya, sehingga masyarakat dapat memahami dengan benar sebelum mengucapkan, menyampaikan dan mempraktekkan gagasan terkait dengan gender. ${ }^{13}$

Kata gender berasal dari bahasa latin "genus" yang berarti tipe atau jenis. Gender bermakna sebuah konsep kultural yang memiliki upaya untuk membuat pembeda dalam berbagai hal, contoh dalam perilaku, mentalitas, karakteristik emosional dan peran, antara laki-laki dan perempuan yang berkembang di masyarakat. ${ }^{14}$ Gender disebut sebagai sifat yang terdapat pada laki-laki ataupun perempuan yang diinterpretasikan dengan cara sosial atau kultural, sebagai contoh perempuan memiliki sifat cantik, emosional, lemah lembut dan lain sebagainya. Sedangkan sifat laki-laki rasional, kuat, perkasa, jantan, dan

${ }^{12}$ Lexy J. Moleong, 'Metodologi Penelitian Kualitatif (Edisi Revisi)', in PT. Remaja Rosda Karya, 2017. Hal. 4.

${ }^{13}$ Siti Zubaedah, 'Mengurai Problematika Gender Dan Agama', Jurnal Studi Gender $\mathcal{E}$ Anak, 2010.

${ }^{14}$ Helen Tierney, Women's Studies Encyclopedia (New York: Green Wood Press). Hal. 153. 
laki-laki, cenderung tidak boleh menangis. ${ }^{15}$ Gender juga dapat disebut sebagai suatu konsep yang sering digunakan untuk memberi identitas perbedaan antara laki-laki dan perempuan dalam hal perilaku, peran dan lainnya yang sudah berkembang di tengah masyarakat berdasarkan pada kondisi kemasyarakatan tertentu. ${ }^{16}$ Maka dapat difahami bahwa gender merupakan peran, fungsi, sikap, tanggung jawab, hak dan kepribadian yang ada pada laki-laki dan perempuan, akibat dari pertumbuhan budaya yang ada pada lingkungan masyarakat tempat di mana mereka tumbuh. Perilaku yang spesifik bagi perempuan dan laki-laki itu lebih dikenal dengan istilah feminim dan maskulin.

Perbedaan atau ketidaksetaraan gender telah meluas dikalangan masyarakat akibat dari dampak budaya patriarki yang telah ada di masyarakat sejak lama. Budaya tersebut telah meluas dikalangan masyarakat, khususnya dalam dunia pendidikan yang seharusnya mengangkat perspektif kesetaraan gender, namun dunia pendidikan juga belum seutuhnya mampu memberikan pemahaman yang benar. Pemahaman tersebut terjadi dan bahkan dipelihara dalam buku-buku pelajaran di sekolah. Hasil analisis isi buku pelajaran -utamanya- dalam buku pendidikan bahasa Arab yang digunakan di sekolah dasar hingga sekolah menengah menunjukkan bahwa teks dan ilustrasi buku banyak menonjolkan anak laki-laki dari pada anak perempuan. Anak laki-laki yang tergambar dalam buku pelajaran tersebut juga lebih beragam, kreatif perannya, dan banyak disebut dibanding anak perempuan. ${ }^{17}$

Dalam kajian gender ini dimaksudkan untuk mengetahui apakah para penulis buku ajar, khususnya penulis buku pendidikan bahasa Arab sudah menampung kesetaraan gender dalam hal mengilustrasikan teks dan gambar perempuan dan laki-laki secara seimbang.

\section{Pola Diskriminasi Gender}

15 Mansour Faqih, Analisis Gender Dan Transformasi Sosial (Yogyakarta: Pustaka Pelajar, 2007). Hal. 8-9.

16 Nasarudin Umar, Argumen Kesetaraan Gender Perspektif Al-Qur'an (Jakarta: Paramadina, 2001). Hal. 35.

17 Santi Dewiki, 'Perspektif Gender dalam Bahan Ajar Cetak pada Pendidikan Jarak Jauh Studi Kasus : Bahan Ajar Cetak Program Studi D2 Pendidikan Olahraga FKIP-UT', Jurnal Pendidikan, 9.1 (2008). Hal. 41-50. 
Dalam konteks hukum diskriminasi, ${ }^{18}$ seks dan jenis kelamin sudah dibangun secara sosial dan terbuka sebagai aturan lebih dipilih dari pada istilah gender. ${ }^{19}$ Menurut Julie A. Greenberg, Pakar hukum Amerika Serikat, bahwa Gender dan seks memiliki sebuah konsepsi yang berbeda, kedua kata tersebut memiliki hubungan fungsi yang berbeda dan kecenderungan diskriminasi gender itu sering kali terjadi akibat dari penilaian terhadap seseorang hanya berdasarkan persepsi masing-masing seks. ${ }^{20}$ Ketika dikaji lebih dalam tentang permasalahan gender dalam kehidupan masyarakat sosial, maka akan menemukan konsep ketidakadilan atau diskriminasi gender, dalam hal ini salah satu jenis kelamin terabaikan hak dasarnya, tertinggal dan mengalami masalah ketidakadilan. Berikut ini adalah beberapa bentuk dari pola diskriminasi gender:

\section{Stereotype (Citra Baku)}

Stereotype atau yang biasa disebut dengan Citra baku, pelabelan atau penandaan yang mengandung unsur ketidakadilan pada salah satu jenis kelamin dan bersifat negatif, mengakibatkan kerugian bagi kaum perempuan, dengan citra baku dan pelabelan tersebut. Perempuan merasa kesulitan dalam berekspresi dan mengembangkan potensi dirinya di berbagai bidang, juga menyulitkan perempuan untuk keluar dari visualisasi negatif masyarakat. ${ }^{21}$

\section{Subordination (Penomorduaan)}

Penomorduaan merupakan suatu anggapan yang mendasar tentang keyakinan bahwa salah satu jenis kelamin tertentu lebih diutamakan dibanding jenis kelamin lainnya. Anggapan tersebut

${ }^{18}$ Diskriminasi adalah ketidak adilan terhadap individu tertentu, dan juga merupakan suatu kejadian yang biasa dijumpai dalam kehidupan Masyarakat, ini disebabkan karena kecenderungan sikap manusia yang lebih suka membeda-bedakan yang lain.

${ }^{19}$ M Render, 'Misogyny, Androgyny, and Sexual Harassment: Sex Discrimination in a Gender-Deconstructed World', Journal of Law E Gender, 29.1 (2006). Hal. 99-150.

${ }^{20}$ Greenberg JA, "'Defining Male and Female: Intersexuality and the Collision Between Law and Biology"', Arizona Law Review, 41 (1999). Hal. 265.

${ }^{21}$ Shodiq, 'Perspektif Kesetaraan Gender Dalam Buku Bahasa Arab Siswa MTs Pendekatan Saintifik 2013'. 
dapat mengakibatkan kurangnya pengakuan terhadap perempuan terkait pengambilan kebijakan, sehingga seorang perempuan merasa sangat sulit untuk mendapatkan posisi kedudukan yang strategis dan sentral dalam suatu perkumpulan atau komunitas, terlebih lagi dalam dunia pekerjaan yang akan mereka hadapi. Adapun yang memiliki sumber keuangan atau ekonomi terbatas, maka diambil keputusan bahwa anak laki-laki harus tetap bersekolah dan anak perempuan tinggal di rumah. ${ }^{22}$

\section{Marginalization (Peminggiran)}

Marginalisasi atau yang biasa disebut sebagai peminggiran umumnya terjadi pada kaum wanita. Penyebab terjadinya sangat beragam seperti keyakinan, tradisi, kebijakan pemerintah, tafsiran agama dan pengetahuan. Fakta yang paling kongkret dari marginalisasi ini adalah kurangnya peluang bagi perempuan pada sektor-sektor ekonomi. Akibat dari kurangnya peluang perempuan pada sektor ekonomi tersebut menjadikan perempuan kelompok miskin dikarenakan peminggiran yang terjadi dalam masyarakat. ${ }^{23}$

Terdapat dugaan bahwasanya seorang perempuan tidak perlu melanjutkan ke jenjang sekolah yang tinggi, dikarenakan nantinya akan melakukan pekerjaan yang sifatnya domestik. Bahkan kondisi perempuan saat memasuki dunia kerja, mereka akan mendapat posisi yang rendah dengan pendapatan yang rendah pula dikarenakan tidak memiliki keterampilan. ${ }^{24}$

\section{Violence (Kekerasan)}

Kekerasan terhadap gender, tidak hanya terjadi secara fisik, melainkan juga terhadap mental psikologis seseorang. Sumber kekerasan tidak hanya terjadi pada satu individu saja melainkan juga kelompok, akibat dari ketidak-seimbangan kekuasaan antara perempuan dan laki-laki yang melahirkan sebuah perbuatanvtidak sesuai, misal pemerkosaan, kekerasan dalam rumah tangga dan

${ }^{22}$ Leli Nurohmah dkk, Kesetaraan Kemajemukan Dan Ham (Jakarta: Rahima). Hal. 13.

${ }^{23}$ Mansour Faqih ...., Hal. 14.

${ }^{24}$ Muhammad Jafar Shodiq, 'Perspektif Kesetaraan Gender Dalam Buku Bahasa Arab Siswa MTs Pendekatan Saintifik 2013', FENOMENA, 2016. Hal. 5-6 $<$ https://doi.org/10.21093/fj.v8i1.302>. 
lain sebagainya. Juga pembentukan peran dimana seorang perempuan ditempatkan pada posisi yang lebih rendah akibat dari budaya patriarkial. ${ }^{25}$

\section{Double Burden (Beban Ganda)}

Sebuah situasi yang menyebabkan seseorang harus menanggung beban kerja berlipat. Terdapat sebuah anggapan bahwasanya perempuan tidak cocok untuk menjadi kepala keluarga yang harus melakukan pekerjaan di sektor publik dikarenakan memiliki sifat menjaga, penyayang dan sabar maka semua pekerjaan domestik menjadi tanggungjawab penuh seorang perempuan. Namun untuk kondisi keluarga yang terbilang memiliki ekonomi kurang baik, seorang perempuan selain memiliki tanggungjawab pada pekerjaan domestik, juga bertanggungjawab atas keberlangsungan hidup keluarga, dengan cara mencari pekerjaan atau mata pencaharian lain. Statement seperti ini yang menjadikan seorang perempuan harus bekerja lebih ekstra untuk melakukan kedua bebannya.

Sebenarnya perbedaan gender tidak menjadi masalah selama tidak melahirkan ketidakadilan gender. Tetapi yang menjadi persoalan adalah ternyata perbedaan gender telah melahirkan ketidakadilan yang akan dialami oleh laki-laki maupun perempuan. Namun dengan berkembangannya zaman seperti saat ini telah banyak orang yang memiliki pengetahuan yang cukup luas sehingga pemikiran mereka tidak hanya dari satu sisi saja melainkan dengan banyak pertimbangan, dan ketika menghadapi persoalan seperti ini akan mendapat solusi yang terbaik tanpa memunculkan ketidakadilan gender.

\section{Hasil dan Pembahasan}

\section{Buku Pendidikan Bahasa Arab Al-'Ashri Kelas X SMA Muhammadiyah}

Buku pendidikan bahasa Arab Al-'Ashri kelas X telah dicetak pertamakali pada 2013 dan disusun berdasarkan kurikulum Majelis Pendidikan Dasar dan Menengah Pimpinan Wilayah Muhammadiyah Jawa Timur dan kurikulum 2013 (K13). Materi dalam buku ini merupakan pengembangan dari kurikulum 2007 yang ditetapkan Majelis Dikdasmen

${ }^{25}$ Kekerasan bisa berbentuk pemerkosaan terhadap perempuan, kekerasan dalam perkawinan, aksi pemukulan dan serangan non-fisik dalam rumah tangga. 
Pimpinan Pusat Muhammadiyah. Penulis buku ini adalah Budi Sunariyanto, M.Pd.I dan Muhammad Taufiqurrohman, S.Pd. sedangkan penyelia buku ini adalah Drs. Zainal Arifin, M.Pd.I. Editor dari buku ini Faishol Ahmad, S.Pd.I dan Riza Arif Achmadi, S.Th.I. Buku bahasa Arab Al'Ashri memiliki ukuran 15,5x23,5 cm dan tebal iv+84 halaman. Buku ini telah terdaftar di ISBN (International Standard Book Number) dengan nomor 978-602-8217-56-9 (no.jil.lengkap) dan nomor 978-602-8217-57-6 (jil.1). ${ }^{26}$

\section{Gender Dalam Buku Pendidikan Bahasa Arab Al-'Ashri Kelas X Sekolah Menengah Atas Muhammadiyah}

Analisis Gender dalam buku pendidikan bahasa Arab Al-'Ashri ditemukan berbagai bentuk. Sebagian terlihat dalam bentuk teks dan sebagian lagi berbentuk gambar. Berikut ini adalah paparan analisis gender dalam buku pendidikan bahasa Arab:

Gambar I: Cover Buku Bahasa Arab Al-'Ashri
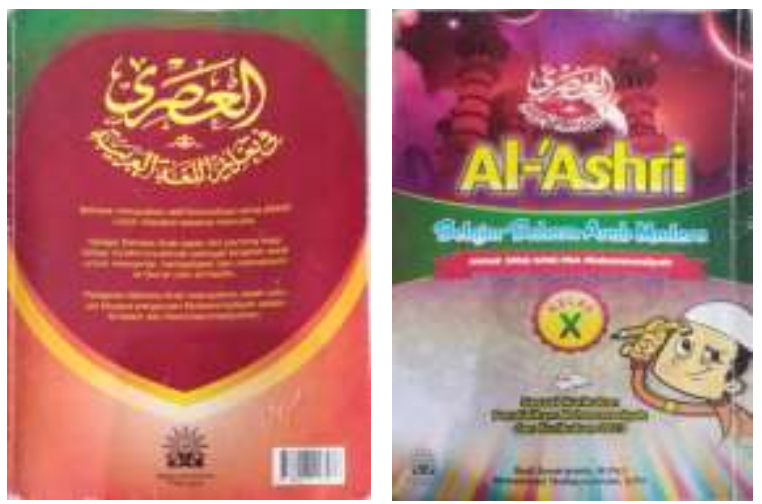

Buku ini terdiri atas $8 \mathrm{Bab}$, pada masing-masing bab terdiri dari alMufrodat, al-Muhadatsah, al-Qoidah, al-Tamrinat, al-Qiro'ah. Bab 1 hingga bab 4 digunakan sebagai materi semester gasal, sedangkan bab 5 hingga bab 8 digunakan sebagai materi semester genap, sebagaimana dalam tabel berikut:

Tabel I: Cakupan Materi

\begin{tabular}{|c|c|c|}
\hline Bab & Judul & Semester \\
\hline 1 & التّعارف & Gasal \\
\hline 2 & الأسرةة & Gasal \\
\hline 3 & المدرسة & Gasal \\
\hline 4 & & \\
\hline
\end{tabular}

${ }^{26}$ Budi Sunariyanto dan M. Taufiqurrohman, Al-`Ashri:Belajar Bahasa Arab Untuk SMA/SMK/MA Muhammadiyah Kelas X (Surabaya: Majelis Dikdasmen PWM Jatim, 2013). 


\begin{tabular}{|l|c|l|}
\hline 5 & Genap \\
\hline 6 & يوم الخصى المستشفى & Genap \\
\hline 7 & Genap \\
\hline 8 & الرحلة & Genap \\
\hline
\end{tabular}

Peneliti menemukan beberapa pola diskriminasi gender pada buku bahasa Arab Al- 'Ashri Kelas X. Temuan itu terdapat pada pengilustrasian sebuah peran yang dikonfigurasi menggunakan gambar dan tulisan. Peran antara lakilaki dan perempuan dikelompokkan dalam sektor publik dan domestik, adapun pada sektor peran publik lebih banyak didominasi oleh laki-laki sementara perempuan mendominasi pada sektor peran domestik.

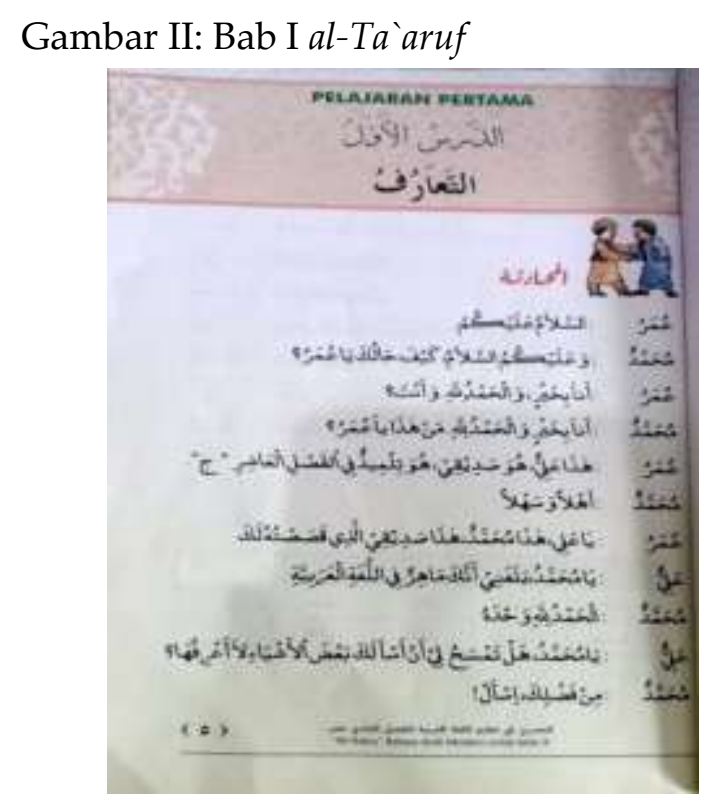

Gambar II di atas terdapat pada halaman 5, jika dilihat dari gambar diatas mengandung unsur Subordination (penomorduaan) yang menggambarkan sebuah percakapan yang memunculkan tokoh hanya laki-laki saja, tidak mengikutsertakan tokoh perempuan dalam percakapan tersebut. Jika diamati dari judulnya adalah al-Ta`aruf, semestinya tokoh perempuan juga harus diikutsertakan dalam percakapan tersebut. Karena materi tersebut ada dalam buku ajar siswa yang mencakup siswa dan siswi, dan mereka yang menggunakan buku itu untuk belajar. Maka, partisipasi tokoh laki-laki dan perempuan menjadi penting ketika dihadapkan pada buku bahan ajar bagi siswa dan siswi. Alternatifnya, penulis menyediakan dua percakapan sekaligus dengan dua tokoh 
laki-laki dan dua tokoh perempuan. Atau penulis hanya memberikan contoh satu percakapan saja dengan dua tokoh yang berbeda gender; laki-laki dan perempuan.

\section{Gambar III: Bab II al-Usroh}
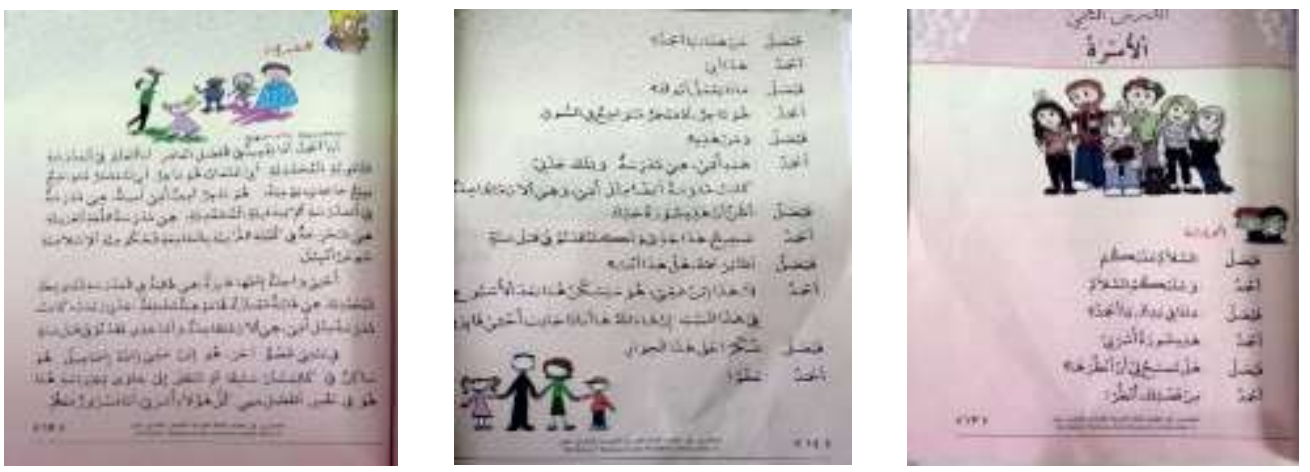

Percakapan dalam gambar III diatas terdapat pada halaman 13-14 bab alUsroh. Percakapan ini mengandung unsur Subordination (Penomorduaan) yang menggambarkan sebuah percakapan yang hanya dilakukan oleh dua orang, sedangkan jika dilihat dari judulnya yaitu al-Usroh, semestinya perempuan juga dapat dimasukkan menjadi tokoh dalam percakapan tersebut. Sebab struktur anggota keluarga tentu tidak hanya laki-laki, tetapi terdapat anggota perempuan didalamnya; ibu, nenek, adik perempuan, kakak perempuan dan lainnya.

Ketika perempuan diikutsertakan menjadi tokoh dalam sebuah bacaan, ditemukan citra baku perempuan terdapat pada domestiknya saja. Teks pada halaman 19 digambarkan bahwa seorang ayah memiliki profesi sebagai pedagang dan seorang ibu memiliki profesi sebagai guru, dapat dilihat bahwa dari teks tersebut mengandung unsur Stereotype (Citra Baku) bahwa laki-laki identik dengan pekerjaan publik karena sesuai anggapan, laki-laki memiliki fisik yang kuat dan maskulinitas sedangkan perempuan identik dengan pekerjaan domestik karena perempuan tergolong sabar, telaten dan feminim.

Gambar IV: Bab II dan Bab VI al-Usroh dan Yaumul Khoshmi
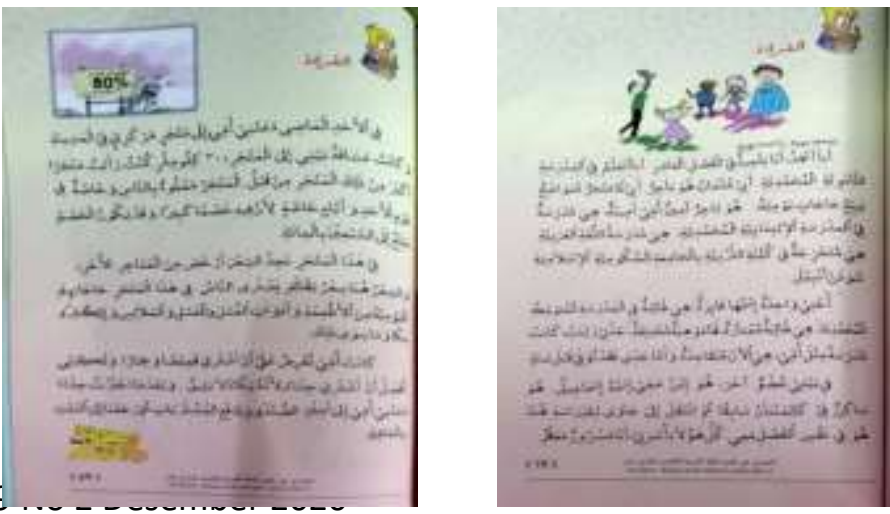
Dalam gambar IV teks diatas berpotensi memunculkan terjadinya Double Burden (Beban Ganda). Perempuan di halaman 19 memiliki pekerjaan sebagai guru dan di halaman 59 seorang perempuan digambarkan sebagai seorang ibu yang sedang mengurus dan menjaga anaknya. Dapat diartikan bahwa seorang perempuan dapat melakukan pekerjaan ganda.

Gambar V: Bab III al-Fasl
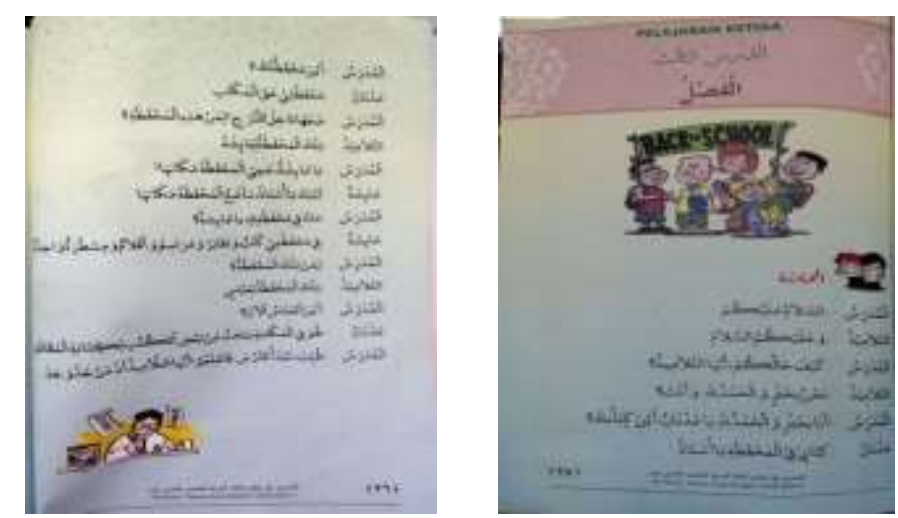

Gambar V di atas terdapat pada halaman 25, jika dilihat gambar tersebut mengandung unsur Subordination (Penomorduaan) yang menggambarkan sebuah percakapan yang dilakukan oleh guru, murid laki-laki dan perempuan. Tetapi dalam percakapan tersebut seorang guru hanya menanyakan tentang isi tas pada murid perempuan saja, seharusnya guru menanyakan kepada semua agar tidak ada kesenjangan diantara mereka.

\section{Gambar VI: Bab IV al-Madrosah}

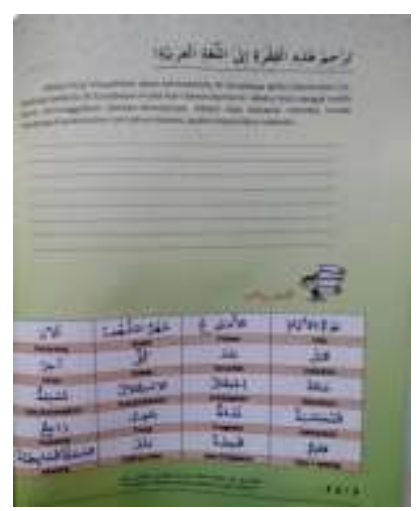

Cerita dalam gambar VI diatas terdapat pada halaman 40 yang menggambarkan seorang anak laki-laki yang akan bersekolah, pada gambar tersebut tidak diceritakan seorang anak perempuan yang akan bersekolah juga. Karena terdapat sebuah anggapan bahwasanya tidak perlu bagi anak perempuan untuk melanjutkan ke jenjang sekolah yang lebih tinggi dikarenakan pada akhirnya juga akan mengurusi pekerjaan domestik salah satu contohnya yaitu 
pekerjaan dapur, sedangkan pada zaman seperti saat ini banyak seorang perempuan yang memiliki gelar sekolah yang tinggi. Maka, jika dilihat dari gambar tersebut mengandung unsur Marginalization (Peminggiran).

Gambar VII: Bab V Fii al-Mustasfa
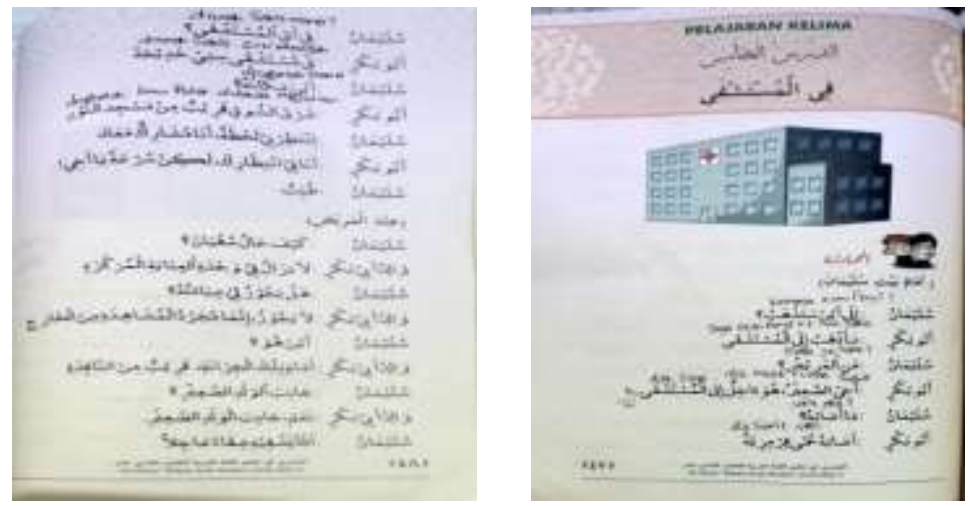

Gambar VII di atas terdapat pada halaman 47, jika dilihat dari gambar di atas mengandung unsur Subordination (Penomorduaan) yang menggambarkan sebuah percakapan dimana hanya laki-laki yang melakukannya, perempuan tidak diikutkan dalam percakapan tersebut, karena dianggap perempuan hanya dapat melakukan pekerjaan domestik.

\section{Gambar VIII: Bab VIII al-Rihlah}

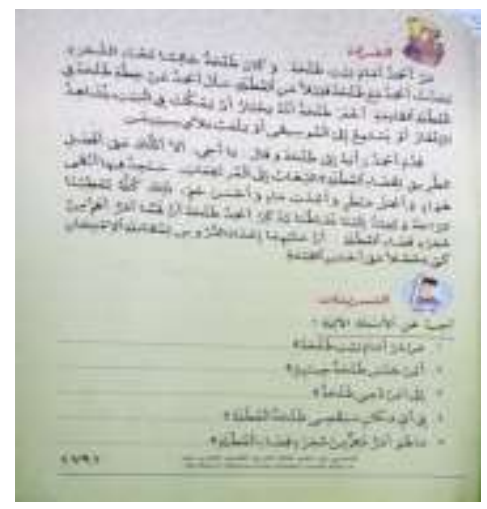

Cerita pada gambar diatas terdapat pada halaman 79, yang menceritakan tentang dua anak laki-laki yang akan menghabiskan liburan dengan mendaki gunung dan akan mendirikan tenda disana. Pada cerita tersebut tidak didapati seorang perempuan, menunjukkan bahwa perempuan dianggap lemah, hal ini mempersulit perempuan untuk mengembangkan potensi diri.Jika dilihat dari cerita tersebut menunjukkan unsur Stereotype (Citra Baku).

\section{Kesimpulan}

Konsep gender bagi siswa dapat diterapkan dalam buku ajar pada sekolah, dengan bentuk penyusunan bahan ajar yang memiliki perspektif gender secara porposional. Isi yang ada dalam buku ajar bagi siswa dapat 
mempengaruhi tingkat perkembangan siswa dalam bidang sosial kemasyarakatan. Buku ajar yang didalamnya berisi pesan tentang kesetaraan gender tanpa adanya tendensi diskriminatif dan subordinatif, akan menghasilkan mutu seorang siswa atau peserta didik yang mampu memahami makna kesetaraan gender. Maka dari itu, harapan untuk seorang guru agar mampu melakukan pembaharuan dalam buku bahan ajar yang di dalamnya terdapat ilustrasi gambar dan teks yang responsif gender. Maka, untuk saat ini diperlukan model pembelajaran peka gender. Perlu diketahui bahwa ilustrasi gambar maupun teks yang ada dalam buku ajar bagi siswa akan lebih mudah dipahami dan diamalkan oleh siswa dalam kehidupan sehari-hari. Untuk itu pembenahan bahan ajar disekolah sangat perlu dilakukan dengan menanamkan perspektif gender.

Buku pendidikan bahasa Arab "Al-'Ashri kelas X" Sekolah Menengah Atas Muhammadiyah masih mengandung unsur ketidaksetaraan gender, dimana dalam buku tersebut masih terdapat perbedaan antara laki-laki dan perempuan yang masuk dalam pola gender Stereotype (Citra Baku), Subordination (Penomorduaan), Marginalization (Peminggiran) dan Double Burden (Beban Ganda). Adapun peran keduanya antara laki-laki dan perempuan masih belum bisa dikatakan seimbang karena sesuai dengan analisa buku tersebut kedudukan seorang laki-laki menempati peran sentral sementara kedudukan seorang perempuan pada peran domestik. Dalam penelitian ini pola gender Violence (Kekerasan) belum ditemukan oleh penulis dalam buku pendidikan bahasa Arab "Al-'Ashri kelas X" Sekolah Menengah Atas Muhammadiyah.

\section{Daftar Pustaka}

Budi Sunariyanto dan M. Taufiqurrohman, Al-'Ashri:Belajar Bahasa Arab Untuk SMA/SMK/MA Muhammadiyah Kelas X (Surabaya: Majelis Dikdasmen PWM Jatim, 2013)

Dewiki, Santi, 'PERSPEKTIF GENDER DALAM BAHAN AJAR CETAK PADA PENDIDIKAN JARAK JAUH Studi Kasus : Bahan Ajar Cetak Program Studi D2 Pendidikan Olahraga FKIP-UT', Jurnal Pendidikan, 9.1 (2008), 41-50

Greenberg JA, "'Defining Male and Female: Intersexuality and the Collision Between Law and Biology"', Arizona Law Review, 41 (1999), 265

Jatmikowati, Tri Endang, Ria Angin, and Ernawati Ernawati, 'MODEL DAN MATERI PENDIDIKAN SEKS ANAK USIA DINI PERSPEKTIF GENDER UNTUK MENGHINDARKAN SEXUAL ABUSE', Jurnal Cakrawala Pendidikan, 2015 <https://doi.org/10.21831/cp.v3i3.7407>

Krissandi, Apri Damai Sagita, and Rusmawan Rusmawan, 'KENDALA GURU SEKOLAH DASAR DALAM IMPLEMENTASI KURIKULUM 2013', Jurnal Cakrawala Pendidikan, 2015 <https://doi.org/10.21831/cp.v3i3.7409>

Leli Nurohmah dkk, Kesetaraan Kemajemukan Dan Ham (Jakarta: Rahima) 
Mansour Faqih, Analisis Gender Dan Transformasi Sosial (Yogyakarta: Pustaka Pelajar, 2007)

Moleong, Lexy J., 'Metodologi Penelitian Kualitatif (Edisi Revisi)', in PT. Remaja Rosda Karya, 2017

MZ, Zubaidah Amir, 'PERSPEKTIF GENDER DALAM PEMBELAJARAN MATEMATIKA', Marwah: Jurnal Perempuan, Agama Dan Jender, 2013 $<$ https://doi.org/10.24014/marwah.v12i1.511>

Nasarudin Umar, Argumen Kesetaraan Gender Perspektif Al-Qur'an (Jakarta: Paramadina, 2001)

Render, M, 'Misogyny, Androgyny, and Sexual Harassment: Sex Discrimination in a Gender-Deconstructed World', Journal of Law E Gender, 29.1 (2006), 99_ 150

Rokhmansyah, Alfian, Pengantar Gender Dan Feminisme:Pemahaman Awal Kritik Sastra Feminisme (Yogyakarta: Garudhawaca, 2016)

ROSYAD, MS, 'ANALISIS BUKU AJAR BAHASA ARAB SISWA KELAS VIII MTs/SMP ISLAM DALAM PERSEPEKTIF GENDER', Journal of Applied Linguistics and Islamic Education, $2.2 \quad$ (2018) <https://doi.org/http://dx.doi.org/10.33754/jalie.v2i2.188>

Shodiq, Muhammad Jafar, 'Perspektif Kesetaraan Gender Dalam Buku Bahasa Arab Siswa MTs Pendekatan Saintifik 2013', Fenomena, 8.1 (2016), 1-18 <https://doi.org/10.21093/fj.v8i1.302>

- - - 'Perspektif Kesetaraan Gender Dalam Buku Bahasa Arab Siswa MTs

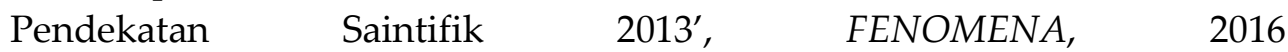
<https://doi.org/10.21093/fj.v8i1.302>

Suryaman, Maman, 'PENGEMBANGAN MODEL BUKU AJAR SEJARAH SASTRA INDONESIA MODERN BERPERSPEKTIF GENDER', LITERA, 2013 <https://doi.org/10.21831/ltr.v12i01.1333>

Syairi, Khairi Abu, 'Pengembangan Bahan Ajar Bahasa Arab | Abusyairi | Dinamika Ilmu', Dinamika Ilmu, 2013

Taufiq, Mirwan Akhmad, 'منهج تعليم العربية لأغراض خاصة؛ خصائصه ومشكلاته', Arabia, 2018 $<$ https://doi.org/10.21043/ARABIA.V10I2.4275>

Tierney, Helen, Women's Studies Encyclopedia (New York: Green Wood Press)

Wahzudik, Niam, 'Kendala Dan Rekomendasi Perbaikan Pengembangan Kurikulum Di Sekolah Menengah Kejuruan', Indonesian Journal of Curriculum $\begin{array}{lll}\text { and Educational Technology } & 2018\end{array}$ $<$ https://doi.org/10.15294/ijcets.v6i2.26712>

Zubaedah, Siti, 'Mengurai Problematika Gender Dan Agama', Jurnal Studi Gender $\mathcal{E}$ Anak, 2010 